\title{
TRANSFORMATION OF LEASED LAND USE OF AGRICULTURAL ENTERPRISES IN UKRAINE IN LIMITED LAND MARKET
}

\author{
Kolosa Liudmyla ${ }^{1}$, Hunko Liudmyla ${ }^{1}$ \\ ${ }^{1}$ National University of Life and Environmental Sciences of Ukraine
}

\begin{abstract}
The result of the long existence of legal restrictions on the agricultural land market in Ukraine was the formation of a specific leasehold system of land use. Agricultural enterprises and farms do not have land owned. Instead, the peasants who became owners of land during the distribution of collective farms, mostly do not process these parcels of land on their own, but also deprived of the right to alienate them (to sell, give, change). The study shows the development of leased land use of agricultural enterprises in Ukraine, which currently covers 16.8 million hectares of private land and about 1 million hectares of state-owned land. Since 2003, the civil law of Ukraine permitted to apply not only the lease of agricultural land, but also the emphyteusis right (the alienated right to use someone's land for agricultural purposes), the process of transformation of lease into emphyteusis was started, especially in large agricultural holdings. The main advantages of emphyteusis as a substantive law and its attractiveness for agribusiness are considered. The suggestions on improving the legal regulation of land use under conditions of emphyteusis are given.
\end{abstract}

Key words: land reform, land lease, agricultural land, emphyteusis, land market.

\section{Introduction}

The Ukrainian model of land reform can be considered one of the most unique and long-lasting in the world, characterized by a complex of features.

Despite the fact that the reform of land relations in Ukraine has been going on for more than 26 years, this process is characterized by the prolongation of a formal temporary ban (the so-called moratorium) on the alienation of land parcels of agricultural purpose by their owners. In particular, according to the World Bank (Deininger K., Nizalov D., 2016) of 41 million hectares of such land, 27.7 million hectares are banned from the alienation of land shares (shares) in kind (on the ground); 10.5 - as agricultural lands of state and communal property; 1.5 - as land for commercial agricultural production (except for share parcels); 1.3 - as non-agricultural lands on agricultural lands of state and communal property; 0.02 million hectares - as uncalled shares. In the conditions of the ban on the alienation of agricultural land, the possibility of their transfer to the lease remained one of the few economic freedoms available to their owners. With the 2003 adoption of the Civil Code (Chapter 33), it became possible to apply not only the lease of agricultural land, but also the rights of the emperor (the alienated right to use someone else's land for agricultural purposes). The use of emphyteusis is gradually becoming more popular among tenants of agricultural land, since it is more profitable and provides flexibility in harmonizing essential conditions of land use.

Regarding the consequences of the land reform and its directions, there are ongoing discussions among leading Ukrainian scientists such as D. Dobryak, R. Kuriltsev, A. Martyn, L. Novakovsky, A. Sokhnich, A. Tretyak, M. Hweisick and many others. However, specific directions of development of rural agricultural land use requires more in-depth research. There remains a debatable problem of improving rental relations on the basis of new legal titles of land use, in particular the rights of emphyteusis.

That is why the article analyzes the consequences of land reform in Ukraine and proposes to improve the legal regulation of land use in terms of emphyteusis.

\section{Methodology of research and materials}

The methodology of studying the problem of transformation of the leased land use of agricultural enterprises determines that the subject of the research is leasehold land relations and the relevant state policy on their regulation. This is characterized by a change in the old forms of organization of lease relations by the new, which is due to the emergence of fundamentally new ties, relations and patterns that determine the tendency of their development in the new conditions of management. The study of these relationships, relations and regularities leads to the scientific knowledge of truth, that is, the objective processes of state regulation of land relations in a market economy. 


\section{Discussion and results}

Land reform is a complex of legal, economic, technical and organizational measures, the implementation of which is aimed at improving, transition to a new land system, an adequate character of a regulated, socially oriented market economy country (Sabluk, 2006).

Independent Ukraine faced an extremely important and difficult task: the creation of a new legal basis for land relations, which would be significantly different from the then, essentially socialist scheme, built on the principles of monopoly law of state ownership of land (Martyn, 2013).

A retrospective analysis of the land reform, an assessment of its positive and negative effects shows that in general, a significant amount of work on the transformation of land ownership, the transfer of most of it, especially agricultural land, to the property of citizens. At the same time, the ultimate goal of reform was not achieved: high-efficiency, ecologically safe use of land resources is not ensured; land relations do not fully meet the requirements of a market economy (Tretyak, 2003).

In Ukraine, for the protection of private property rights of peasants to land (share) in January 2001 a moratorium on the sale of land parcels (shares). In the conditions of the ban on the alienation of agricultural land, the possibility of their transfer to the lease remained one of the few economic freedoms available to their owners. The lease made it possible not to restrict access to land resources of entrepreneurs who had the resources and opportunity for their cultivation. The rent helps to maintain high profitability of agribusiness for a long time, which provided technical re-equipment and modernization of agricultural production.

Implementation of lease relations, in practice, provides additional income to obtain landlord and tenant in accordance with the delivery of the units to rent and use of leased land. In addition, lease relations should be profitable for the state (Kareba, 2012).

According to the World Bank, the average rent of 1 hectare of arable land of Denmark reaches 780.8 dollars USA, Netherlands - 672.1, Ireland - 592.2, Bulgaria - 278.9, Luxembourg - 256.2, Spain 227.3, Germany - 219.4, Belgium - 123.8, Lithuania - 53.7 dollars. US (Deininger, Nizalov, 2016).

At the same time, the rent for agricultural land in Ukraine is 6-8 times lower and equals about \$37. USA. O On the one hand, this is explained by considerably higher incomes of agribusiness in the EU, which, in particular, are formed as a result of the implementation of the EU Common Agricultural Policy. However, there are obviously some disproportions regarding the redistribution of land rent in our state. We show the average cost of land lease in the regions of Ukraine (Table 1).

Table 1

Average indices of the area of leased land and rent in the regions of Ukraine (Kolosa, 2018)

\begin{tabular}{|l|c|c|}
\hline \multicolumn{1}{|c|}{ Region } & Total area of land leased under contracts, ths. ha & Annual rent, USD / ha \\
\hline Vinnitsa & 1051.5 & 56.5 \\
\hline Volyn & 205.2 & 40.08 \\
\hline Dnipropetrovsk & 1276.8 & 38.02 \\
\hline Donetsk & 727.8 & 32.98 \\
\hline Zhytomyr & 588.4 & 47.56 \\
\hline Zakarpattya & 16.7 & 26.97 \\
\hline Zaporozhye & 1144.6 & 29.83 \\
\hline Ivano-Frankivsk & 110.3 & 41.47 \\
\hline Kiev & 797.8 & 57.78 \\
\hline Kirovograd & 1010.6 & 52.93 \\
\hline Lugansk & 637.3 & 32.16 \\
\hline Lviv & 297.7 & 55.3 \\
\hline Nikolaev & 883.4 & 30.99 \\
\hline Odesa & 1085.3 & 36.63 \\
\hline Poltava & 1147.4 & 95.91 \\
\hline Rivne & 256.2 & 56.2 \\
\hline Sumy & 712.6 & 78.89 \\
\hline Ternopil & 502.0 & 46.66 \\
\hline Kharkiv & 1074.9 & 79.3 \\
\hline Kherson & 831.1 & 31.63 \\
\hline Khmelnitsky & 780.1 & 60.18 \\
\hline Cherkassy & 784.3 & 111.24 \\
\hline Chernivtsi & 111.3 & 49.7 \\
\hline Chernihiv & 825.3 & 44.74 \\
\hline Total for Ukraine & $\mathbf{1 6 8 5 8 . 5}$ & 51.43 \\
\hline & & \\
\hline
\end{tabular}


As can be seen, a significantly higher rent for land use in Cherkassy and Poltava regions is 111.24 and 95.91 USD / ha, while in other areas it ranges from 30-55 USD / ha.

The total amount of payments for the lease of land shares in 2015 amounted to about 368 million dollars USA, including tenants having entered into contracts with pensioners-peasants at 158 million dollars, which equals $42.9 \%$ of the total payments for this year (StateGeoCadastre, 2015).

In total, in 2015, land parcel holders concluded 4741.4 thousand land lease agreements, of which the majority - 2477.5 thousand were signed by peasant pensioners; 1863.7 thousand land lease agreements were registered for 4-5 years, 2004.2 for 6-10 years, 659 for 10 years or more, ie $95.5 \%$ of contracts are long-term (StateGeoCadastre, 2015).

In addition, $74.4 \%$ of contracts concluded with a rent of $3 \%$ or more of the normative monetary valuation of land parcels. The average rent amount for the year is 21,18 USD / ha, and the area of land leased by the owners of land shares reaches 17.5 million ha (StateGeoCadastre, 2015).

We give indicators of the conclusion of lease agreements for state-owned land in terms of administrative-territorial units of Ukraine for 2015 (Table 2).

Table 2

Conclusion of lease agreements for state-owned land in the regions of Ukraine, 2015 *

\begin{tabular}{|c|c|c|c|c|c|c|}
\hline \multirow{3}{*}{ Region } & \multicolumn{6}{|c|}{ Lease agreements for maintenance are concluded } \\
\hline & \multicolumn{2}{|c|}{$\begin{array}{c}\text { Commodity agricultural } \\
\text { production }\end{array}$} & \multicolumn{2}{|c|}{ Farming } & \multicolumn{2}{|c|}{ Private peasant farming } \\
\hline & units & area, ha & units & area, ha & units & area, ha \\
\hline Vinnitsa & 1852 & 60190.56 & 558 & 19124.44 & 16 & 13.50 \\
\hline Volyn & 433 & 12155.52 & 261 & 5047.54 & 159 & 131.10 \\
\hline Dnipropetrovsk & 1103 & 31929.32 & 722 & 18219.61 & 22 & 120.31 \\
\hline Donetsk & 998 & 42208.20 & 447 & 19700.08 & 22 & 32.58 \\
\hline Zhytomyr & 212 & 5535.93 & 311 & 9895.51 & 41 & 288.76 \\
\hline Zakarpattya & 41 & 1497.13 & 49 & 462.51 & 33 & 84.72 \\
\hline Zaporozhye & 1595 & 51893.69 & 373 & 14813,38 & 55 & 97.44 \\
\hline Ivano-Frankivsk & 35 & 373.82 & 98 & 1620.90 & 11 & 88.69 \\
\hline Kiev & 361 & 10421.45 & 301 & 8545.67 & 40 & 516.83 \\
\hline Kirovograd & 4074 & 133592.29 & 398 & 11224.62 & 164 & 186.48 \\
\hline Lugansk & 413 & 22417.76 & 243 & 8923.55 & 128 & 751.80 \\
\hline Lviv & 79 & 1613.96 & 113 & 1593.46 & 11 & 8.90 \\
\hline Nikolaev & 1676 & 49767.89 & 387 & 10618.83 & 21 & 33.61 \\
\hline Odesa & 479 & 28535.62 & 163 & 5044.58 & 76 & 78.97 \\
\hline Poltava & 3757 & 89032.53 & 469 & 12594.88 & 310 & 574.88 \\
\hline Rivne & 78 & 584.80 & 40 & 495.95 & 7 & 15.72 \\
\hline Sumy & 1389 & 66624.37 & 137 & 7897.29 & 48 & 28.26 \\
\hline Ternopil & 370 & 6384.94 & 229 & 4900.61 & 72 & 58.48 \\
\hline Kharkiv & 2643 & 82304.24 & 490 & 13558.36 & 33 & 76.36 \\
\hline Kherson & 1185 & 94743.99 & 354 & 20652.51 & 67 & 595.94 \\
\hline Khmelnitsky & 921 & 34684.52 & 539 & 17937.99 & 33 & 142.62 \\
\hline Cherkassy & 2183 & 109615.23 & 267 & 8942.32 & 4012 & 1440.72 \\
\hline Chernivtsi & 77 & 605.02 & 51 & 457.01 & 53 & 73.63 \\
\hline Chernihiv & 931 & 39196.85 & 529 & 20066,16 & 356 & 611.61 \\
\hline Kiev city & 0 & 0.00 & 0 & 0.00 & 0 & 0.00 \\
\hline Sevastopol city & 31 & 5104.44 & 0 & 0.00 & 0 & 0.00 \\
\hline Total for Ukraine & 27627 & 1042589 & 7735 & 251807 & 5816 & 6126 \\
\hline
\end{tabular}

* Source: developed according to the data of the StateGeoCadastre for 2015.

Analyzing the above data, one can conclude that, in general, in Ukraine, in 2015, 27627 land lease agreements for commodity agricultural production were concluded on the area of 1042589 hectares; 
7735 contracts with an area of 251807 hectares - for a farm and 5816 contracts on an area of 6126 hectares - for a private farm.

In the context of the increase in the cost of renting agricultural land in connection with the adoption of amendments to the Tax Code of Ukraine, the search for alternative, more economically profitable tools for the use of these lands is becoming more and more relevant. Changes in the Tax Code of Ukraine stipulate, as already noted, that rent for land parcels of state and communal property is not less than $3 \%$ of its normative monetary valuation.

One such instrument is the emphyteusis - the right to use the land parcel for agricultural needs as a separate type of property right provided for by the Civil Code of Ukraine. The use of this tool is gradually becoming more popular among tenants of agricultural land, since it is more profitable and provides flexibility in harmonizing the essential conditions of land use (Cherkaska, Fordui, 2013).

Ukraine integrated the legal title of emphyteusis as a right to use another land parcel for agricultural needs in the legal system with the 2003 adoption of the Civil Code (Chapter 33), as well as the introduction of appropriate amendments to the Land Code (Chapter 16). Emphystease may be established by agreement between the owner of the land parcel and the person who has expressed the desire to use it for agricultural needs (the emphyteut). In the future, emphyteut may dispose of its right to use other persons, as well as transfer it to inheritance. As a rule, the contract sets a one-time fee for the transfer of the right to transfer (possibly free of charge) and / or the fee for using it, which is to be paid by the issuer to the owner in a definite manner and agreed time.

Legislation directly provides for the possibility of concluding an indefinite agreement on emphyteusis. In accordance with this agreement, each party may terminate it at any time by notifying the other party not later than one year before. However, for lands of state and communal ownership, the terms of emphyteusis, as well as lease, can not exceed 50 years. For land that is privately owned, the maximum term of the contract is not limited. In practice, there are cases where the contract is concluded for a period of 100 years.

In contrast to the lease, the size of the payment for the use of the land parcel for a contract concluded, to arrange and charge its payments to be settled exclusively by the parties to the contract.

According to the analysis of the given data (Table 3), the conclusion of the agreements on emphyteusis in Ukraine is becoming more and more popular.

Table 3

Number of registered records on the right to use the land for agricultural purposes (emphyteusis), 2013-2015*

\begin{tabular}{|l|l|l|l|}
\hline \multicolumn{1}{|c|}{ Region, district } & 2013 & 2014 & 2015 (as of 22.11.15) \\
\hline Crimea & 18 & 2 & 428 \\
\hline Vinnitsa & 28 & 172 & 1 \\
\hline Volyn & 0 & 0 & 420 \\
\hline Dnipropetrovsk & 98 & 289 & 406 \\
\hline Donetsk & 284 & 767 & 4 \\
\hline Zhytomyr & 1 & 7 & 13 \\
\hline Zakarpattya & 2 & 6 & 824 \\
\hline Zaporozhye & 250 & 775 & 1 \\
\hline Ivano-Frankivsk & 0 & 193 & 364 \\
\hline Kyiv city & 1 & 3 & 782 \\
\hline Kiev & 29 & 736 & 141 \\
\hline Kirovograd & 217 & 606 & 13 \\
\hline Lugansk & 34 & 266 & 89 \\
\hline Lviv & 0 & 0 & 178 \\
\hline Nikolaev & 12 & 34 & 1954 \\
\hline Odesa & 9 & 66 & 0 \\
\hline Poltava & 230 & 696 & 0 \\
\hline Rivne & 0 & 2 & 162 \\
\hline Sevastopol & 1 & 0 & 10 \\
\hline Sumy & 0 & 43 & 385 \\
\hline Ternopil & 325 & 1 & 76 \\
\hline Kharkiv & 397 & 101 & 387 \\
\hline Kherson & 570 & 1692 & 964 \\
\hline Khmelnitsky & 23 & 244 & $\mathbf{7 8 7 2}$ \\
\hline Cherkassy & 335 & 397 & 239 \\
\hline Chernivtsi & 42 & 0 & $\mathbf{7 6 0}$ \\
\hline Chernihiv & 0 & & \\
\hline The total number of & $\mathbf{2 0 6}$ & & \\
\hline
\end{tabular}

* Source: developed according to the StateGeoCadastre. 
As a whole, analyzing the dynamics of concluded contracts of emphyteusis in the period 2011 - I quarter. 2016 years (Fig. 1), it should be emphasized its significant growth over the last two years.

Rental of state and communal agricultural lands on the basis of lease agreements became significantly more costly for the tenant.

The parties to the agreement on emphyteusis may agree on a substantially lower rent or more favourable conditions for its payment than is provided by the legislation for land lease agreements.

The presence of such an opportunity makes the use of emphyteusis extremely cost-effective for the tenant, which contributes to the intensive development of the practice of concluding these agreements in modern conditions.

The parties are obliged to agree in the agreement of emphyteusis only those conditions which they consider essential. It gives the parties much more freedom and allows them to adjust only those conditions that are important to them, which is especially important for foreign investors.

A special distinction between the right to leverage is the possibility of its alienation and inheritance in relation to the land parcel that is privately owned.

In the case of the alienation of the right to leverage, the land user must notify the owner of his intention not later than one month before such alienation, since the holder has a preferential right to acquire the right to the emphyteum.

In addition, an emphyteus agreement may provide for the owner to receive a portion of a percentage of the cost of selling the right to leverage to his land (Cherkaska, Fordui, 2013).

The possibility of alienating the right to the emphyteus actually should mean transferring it into a pledge, however, unfortunately, in practice this is unrealistic, since the right to leverage is almost not subject to assessment, and registration of its transition on the basis of a pledge agreement is not provided for by law.

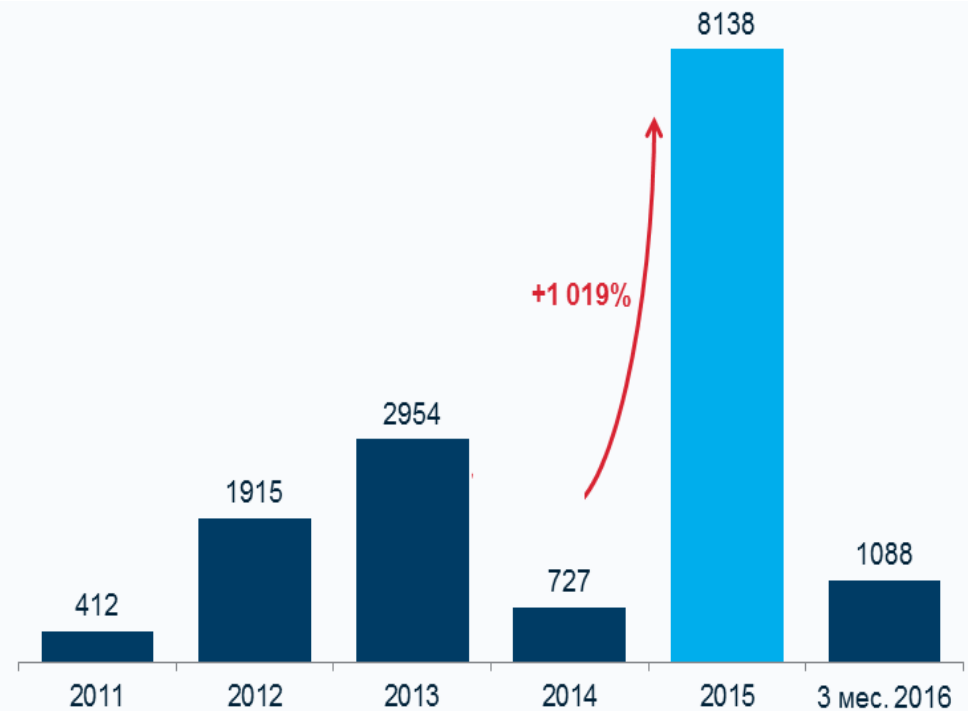

Fig. 1. Dynamics of the number of contracts for emphyteusis (according to the data of the State Geocadaster of Ukraine and Baker-Tilly company)

Rental of state and communal agricultural lands on the basis of lease agreements became significantly more costly for the tenant.

The parties to the agreement on emphyteusis may agree on a substantially lower rent or more favorable conditions for its payment than is provided by the legislation for land lease agreements.

The presence of such an opportunity makes the use of emphyteusis extremely cost-effective for the tenant, which contributes to the intensive development of the practice of concluding these agreements in modern conditions.

The parties are obliged to agree in the agreement of emphyteusis only those conditions which they consider essential. It gives the parties much more freedom and allows them to adjust only those conditions that are important to them, which is especially important for foreign investors.

A special distinction between the right to leverage is the possibility of its alienation and inheritance in relation to the land parcel that is privately owned. 
In case of the alienation of the right to leverage, the land user must notify the owner of his intention not later than one month before such alienation. The proprietor has a preferential right to acquire the right to the emphyteum.

In addition, an emphyteus agreement may provide for the owner to receive a portion of a percentage of the cost of selling the right to leverage to his land [35].

The possibility of alienating the right of emphyteusis must in fact mean transferring it into a pledge, but unfortunately, in practice, it is unrealistic to do so. The right to emphyteusis is almost not subject to evaluation, and registration of its transition on the basis of a collateral agreement is not provided for by law.

Thus, the agreement on emphyteusis is an interesting alternative to the lease of agricultural land and has a number of significant advantages due to the lack of significant regulation of this instrument in Ukrainian legislation.

Emphyteusis is defined as the right to use a parcel of land for agricultural purposes. It is established by an agreement between the owner of the land parcel and the person who has expressed the desire to use it for agricultural needs (land user, emphyteut). In the future, emphyteut may dispose of its right to use and transfer it to inheritance. The agreement establishes the cost of transferring the right to lease money (possibly a free transfer) and payment for the use of this right, which the issuer must pay to the owner in a certain way and for a specified period.

The term of the land use contract for agricultural needs is not limited by law. But for the land state and communal ownership, this period can not exceed 50 years.

First of all, emphyteusis is necessary for those owners of agricultural land, which urgently need money, and their only asset is the land that can not be sold under the terms of the moratorium. Under a lease agreement, they will receive funds in instalments, and under the agreement of emphyteusis - at once a significant amount. The latter is determined by agreement of the parties when signing the contract. It is best to calculate the amount, taking into account the size of the rental rate for this or a similar parcel for the same period. The basis for calculating the cost in the case of a lease is the valuation of the parcel (Vakarash, 2010).

The owner of the land parcel for which the emphyteusis has been established has the right:

- to require the land user to use it according to the purpose established in the contract;

- to receive a fee for using it;

- in case of sale of the right to use the land parcel, the right to purchase it prevails over other persons for the price declared for sale and on other equal terms;

- in case of sale by the land user of the right to use the land parcel for agricultural needs to another person the right to receive the percentage of the sale price (the value of the right) established by the contract. The obligation of the owner of the land parcel is not an obstacle to the land user in the exercise of his rights.

The land user (emphyteut) has the right to use the land parcel in full in accordance with the contract, as well as to dispose of the right to use the land for agricultural purposes, unless otherwise provided by law. In addition, he is obliged: to use the land parcel for the intended purpose, established in the contract; pay the owner of the site a fee for using it; to start using the site for agricultural needs before the expiration of a three-year period from the moment of the establishment of emphyteusis; in case of discontinuation of use, bring the area to the condition in which it was before the establishment of emphyteusis; apply environmental technologies of production; to comply with the requirements of the legislation on the protection of the environment; not to violate the rights of owners of adjacent land parcels and land users; to increase the soil fertility and to preserve other beneficial properties of the earth; adhere to the rules of good-neighbourliness and restrictions related to the installation of land easements and security zones; keep geodetic marks, anti-erosion structures, networks of irrigation and drainage systems; provide timely information on the status and use of land and other natural resources to the executive and local governments.

Consequently, from the moment of the acquisition of the status of emotion in the land user there are also obligations to the state. In particular, the obligation to pay a land tax is not the owner of the land, but the land user. they can not at the same time be tax payers for the same land parcel. In case of violations of land or environmental legislation concerning a parcel that is subject to emphyteusis, legal responsibility will be borne by the land user, and not the land parcel owner.

Emphyteusis terminates on the following grounds: death, destruction of the land parcel or such damage, which excludes the possibility of its use for the intended purpose; agreement of the parties on the termination or refusal of the emotion law (mediation); combination in one person of both parties as 
a result of consolidation (buy-back by the owner of the emphyteutic right) or embezzlement (buy-back by the owner of the ownership of the land); use of land for non-agricultural needs for three consecutive years; redemption of a land parcel in connection with social necessity; the term for which the right of use has been granted has expired. During the sale of the leverage right to a third party at the request of the owner of the owner, a laudemia be paid in the amount established by the contract in the form of a percentage of the sale price.

The right to use the land parcel under the conditions of emphyteusis increasingly attracts the attention of the subjects of agricultural land use. In connection with this, a comparative description of the legal norms set forth in the Law of Ukraine "On Land Lease" (concerning lease) and the Civil Code of Ukraine (concerning the substantive right to another's property - emphyteusis) has been fulfilled (Table 4).

Table 4

Comparative analysis of the conditions of use of land parcels on the legal titles of lease and emphyteusis

\begin{tabular}{|c|c|c|c|c|}
\hline \multirow{2}{*}{$\begin{array}{l}\text { Condition of the } \\
\text { use of the site }\end{array}$} & \multirow{2}{*}{ Right to lease } & \multirow{2}{*}{ The right to emphyteusis } & \multicolumn{2}{|c|}{$\begin{array}{c}\text { Benefits (+) } \\
\text { and disadvantages }(-)\end{array}$} \\
\hline & & & Rent & Emphyteusis \\
\hline Form of provision & $\begin{array}{l}\text { Can be provided to any } \\
\text { person }\end{array}$ & $\begin{array}{l}\text { It is established in favour of the } \\
\text { landowner or land user }\end{array}$ & + & + \\
\hline $\begin{array}{l}\text { Form } \\
\text { acquisition }\end{array}$ & According to the contract & $\begin{array}{l}\text { Acquired accordingly } \\
\text { to the contract }\end{array}$ & $+/-$ & + \\
\hline Notarization & \multicolumn{2}{|c|}{$\begin{array}{l}\text { A lease (emphyteusis) may be certified by a notary public with } \\
\text { the consent of the parties }\end{array}$} & + & + \\
\hline State registration & $\begin{array}{l}\text { The contract is subject to } \\
\text { state registration }\end{array}$ & $\begin{array}{l}\text { The contract is not subject to } \\
\text { mandatory state registration }\end{array}$ & $+/-$ & + \\
\hline $\begin{array}{l}\text { Status of the land } \\
\text { parcel }\end{array}$ & $\begin{array}{l}\text { The land parcel is in } \\
\text { exclusive possession and } \\
\text { use of the tenant for the } \\
\text { duration of the contract }\end{array}$ & $\begin{array}{l}\text { The land parcel is in exclusive } \\
\text { use of the tenant for the duration } \\
\text { of the contract }\end{array}$ & + & + \\
\hline $\begin{array}{l}\text { The status of the } \\
\text { right of the } \\
\text { landowner for the } \\
\text { period of transfer } \\
\text { for use }\end{array}$ & \multicolumn{2}{|c|}{$\begin{array}{l}\text { During the period of the lease agreement (emphyteusis), the } \\
\text { landowner is deprived of the right to use the land parcel }\end{array}$} & + & + \\
\hline Fees for usage & $\begin{array}{l}\text { The fee for the use of land } \\
\text { is set at the legislative } \\
\text { level in the amount of not } \\
\text { less than } 3 \% \text { of the } \\
\text { monetary valuation of such } \\
\text { a parcel }\end{array}$ & $\begin{array}{l}\text { Land use can be carried out both } \\
\text { on a fee and on a royalty-free } \\
\text { basis }\end{array}$ & - & + \\
\hline Duration of use & $\begin{array}{l}\text { The term of use of land } \\
\text { parcels of all forms of } \\
\text { ownership is necessarily } \\
\text { set by the lease, but may } \\
\text { not exceed } 50 \text { years }\end{array}$ & $\begin{array}{l}\text { The use of land parcels of private } \\
\text { property in accordance with the } \\
\text { agreement of emphyteusis may be } \\
\text { established both for a definite and } \\
\text { indefinite period; for land parcels } \\
\text { of state or communal property - } \\
\text { up to } 50 \text { years }\end{array}$ & - & + \\
\hline $\begin{array}{l}\text { Ability to re- } \\
\text { transfer for use }\end{array}$ & $\begin{array}{l}\text { May be transferred to a } \\
\text { sublease, feel at the court's } \\
\text { decision (if it is necessary } \\
\text { for public needs) }\end{array}$ & $\begin{array}{l}\text { May be alienated and transferred } \\
\text { in order of inheritance }\end{array}$ & $+/-$ & + \\
\hline $\begin{array}{l}\text { Status of the right } \\
\text { when returning to } \\
\text { the landowner }\end{array}$ & \multicolumn{2}{|c|}{$\begin{array}{l}\text { The right of use for the land user is not preserved, which is } \\
\text { accompanied by the termination of the contract }\end{array}$} & + & + \\
\hline \multicolumn{3}{|l|}{ Result } & 6.5 & 10 \\
\hline
\end{tabular}

After analyzing the information provided, there are grounds to argue that there are a large number of both common and distinctive features of rental rights and emphyteusis. In accordance with the current situation in the field of agricultural land use in Ukraine, it is worthwhile to identify the strong points that we believe have the right to emphyteusis, namely: 
- emphyteut may take advantage of the right to alienate the emphyteusis to another person by concluding a contract of sale, purchase, sale, donation, etc., but the owner of the land will have a preemptive right to acquire the right of emphyteusis, which will mean his termination;

- the emphyteusis, like the lease, is payable, however, the amount and frequency of the payment for the use of the emphyteusis is established by the agreement between the owner and the issuer, and not by law, as in the case of a lease. When entering into an agreement on the emphyteusis, it is possible to negotiate either periodic payments or regular provision of certain services, or a one-time payment of a certain amount for the entire period of use of the site;

- if the agreement of the emphyteusis is concluded, for example, for a term more than 30 years and provides for a one-time payment for the use of the site by the owner, then such payment is usually close to the market value of the parcel;

- in contrast to the right to lease, only the agricultural land can be used for the right of emphyteusis, that is, private parcels, parcels for cottage or garage construction and other nonagricultural land can not be granted for use in the right of emphyteusis;

- the agreement on the emphyteusis is concluded by the owner and the land user in an arbitrary form;

- if the agreement on the establishment of emphyteusis was certified notarially, the right to use land under these conditions is registered by a notary public, and in the other case registration should be carried out in the local unit of the State Registration Service of Ukraine;

- the agreement on the emphyteusis for land parcel s of private property may be concluded for a certain or indefinite period. If such an agreement is concluded regarding land parcels of state and communal property, the period of its validity can not exceed 50 years;

- when entering into an agreement for an indefinite period, each party may cancel the contract by notifying the other party not less than one year before the desired date of its termination;

- the right to use a foreign land parcel of private property for agricultural needs (emphyteusis) may be alienated and transferred in order of inheritance. That is, if the desire is to transfer the right to use the site to another person, the new user must comply with all obligations of the previous user before the owner;

- in the case of the sale of the user's emotion, the owner of the land parcel prefers, before other persons, the right to purchase it at the price declared for sale and on other equal terms;

- in case of sale by the land user of the right to use the land parcel for agricultural needs to another person, the owner of the land is entitled to receive percentages from the sale price (value of the right) established by the contract.

Thus, the contracts of emphyteusis have certain advantages over lease agreements. They can foresee the alienation and the transfer of the right to use a foreign land for agricultural needs. Unlike the lease agreement, for which the maximum term of the agreement must not exceed 49 years, the emphyteusis has an unlimited period of validity. In addition, in the contract, on the one hand, there is a prohibition on using the land parcel not for its intended purpose, and on the other - the owner of the land parcel guarantees non-interference with the activity of the user of the land. In addition, the list of clearly identified cases where the contract can be terminated is limited.

According to many scholars, emphyteusis is advantageous to agricultural producers, however, this is not quite the way we see it. Agricultural enterprises will be able to use and cultivate land for a long period of time (for example, 15-20 years) and will be interested in maintaining a high level of fertility, and landowners will be able to have a stable long-term income based on market value.

In turn, lease of land can only be effective if the open land market is used for commercial agricultural production with a view to its real alienation. Without this, the rental has fundamental disadvantages. It leads not only to the depletion of land due to inefficient use, but also, absorbing a significant portion of nutrients, greatly reduces the potential for intensive farming.

For a long-term basis, the right to use land for agricultural purposes could be an alternative to such types of loans, such as real estate, vehicles, future crops and foodstuffs.

In view of the above and excessive overregulation of the right to lease land through constant changes to the Law of Ukraine "On land lease", which limit the rights and pose significant risks both to the landowner and land user, we propose to develop set of measures for the transformation of the right to lease into the emphyteusis through legislative and eco-economic instruments.

An important aspect that shows the benefit of emphyteusis is that the permanent registration of lease agreements when changing ownership, inheritance, giving and other civil-law agreements involves 
significant costs for notarial services. These difficulties are a burden on agricultural enterprises and households.

Emphyteusis is a more universal right, which will enable eliminating the above extraordinary transaction costs and promoting the development of leased farm land use.

Consequently, the new mechanism for the formation and redistribution of differential rent between large agricultural producers and small peasant and farmer farms, based on the economic evaluation of agricultural land, should stimulate long-term land use, increase production volumes and become the main factor for changing the ecological, economic and social situation in the countryside.

An important task is to improve the mechanism of sale at the auction of the right of use for agricultural needs (emphytevisis) by land parcels of state and communal property. Under current law, this right may be traded, but the terms for charging for such use (one-time amount or payment of periodic annual payments) are not specified. Proceeding from the traditional understanding of the conditions of land use, it is expedient to sell such a right for a one-time payment, with the starting price of the value of the right to be determined by an expert monetary assessment. We also recommend that amendments be made to the Tax Code of Ukraine, which persons who use land parcels of state and communal ownership on the right to the emphyteusis (and superficies) should be included in the list of land tax payers, and the fee for the use of the right to leverage - to local taxes (on property ) by analogy with the rent for such land, since at present, the Budget Code of Ukraine does not specify the procedure for transferring such a payment to local or state budgets.

\section{Conclusions and proposals}

The main problem of the rental model of agricultural land use is, first of all, the actual removal of the peasants - owners of parcels of land from entrepreneurship and turning them into a rentier who are mainly interested in hiring their own property. As a result of the transformation processes of the Ukrainian economy, alternative models of agricultural land use formation in the agrarian sector are lease and emphyteusis.

The right to emotion as a substantive right includes the powers of ownership and use of another's agricultural land for agricultural needs, and gives the owner of the land and land user greater autonomy in determining the conditions for using the land. It is important that the right of emphyteusis, in contrast to the lease, is a real possibility of its alienation and inheritance. One of the main advantages of the right of emphyteusis is determined by its continuity and the possibility of inheritance. Implementation of this type of right will allow to significantly reduce transaction costs when conducting civil law agreements with land parcels of commodity agricultural production.

So, the agreement on emphyteusis is an interesting alternative to the lease of agricultural land and has a number of significant advantages due to the lack of significant regulation of this instrument in Ukrainian legislation.

\section{References}

1. Deininher K., Nizalov, D. (2016). 26 Years of Land Reform: the Glass is Half-Empty or Half-Full. Vox Ukraine. Viewed 7 October, 2016, (http://www.worldbank.org/uk/news/opinion/2016/10/17/26-years-ofland-reform-the-glass-is-half-empty-or-half-full).

2. Sabluk P. (2006) Development of land relations in Ukraine. Kyiv. 396p.

3. Martyn, A. (2013), "Regulation of land market in Ukraine", Extended abstract of Doctor's thesis, Economics of Nature and Environmental Protection, Kyiv, Ukraine.

4. Tretiak A. (2003) Scientific fundamentals of land use and land management economics. Kyiv. 337 p.

5. Kareba M. (2012). Status and directions of improvement of lease relations in the agrarian sector of the agro-industrial complex. Business Navigator, Volume 1, pp. 10-15., available at: http://nbuv.gov.ua/UJRN/bnav_2012_27_4.

6. Kolosa, L. (2018), "Transformation and optimization of leased agricultural land use", Candidate's thesis, Economics of Nature and Environmental Protection, Kyiv, Ukraine.

7. The State Service of Ukraine for Geodesy, Cartography and Cadastre, available at: http://land.gov.ua/.

8. Cherkaska N., Fordui H. (2013). Concerning the grounds for terminating the agreement on emphyteusis. Law forum, Volume 1, pp. 1135-1140., available at: http://archive.nbuv.gov.ua/e-journals/FP/20131/13hnvpde.pdf.

9. Vakarash V., (2010). Formation and use of land-resource potential of agrarian business in the metropolitan region. Scientific Herald of the National University of Life and Environmental Sciences of Ukraine, Volume 154, Issue 23, pp. 215-221. 
Information about authors:

Liudmyla Kolosa, PhD (Environmental Economics), Head of the Training, Research and Production Center "Protection of Natural Resources and Land Reform", National University of Life and Environmental Sciences of Ukraine. Address: 17 Valylkivska str., Kyiv, 03040, Ukraine; phone: +380972679955; e-mail: kll_ludmila@ukr.net. Fields of interest: land management, land administration, agricultural land-use.

Liudmyla Hunko, Ph.D, Assoc. Prof., Associate Professor of the Land-Use Planning Department, National University of Life and Environmental Sciences of Ukraine. Address: 17 Valylkivska str., Kyiv, 03040, Ukraine; phone: +380503821744; e-mail: liudmyla_g@ukr.net. Fields of interest: land management, land administration, spatial planning, agricultural land-use. 